\title{
PLANT ANATOMY AS A TOOL FOR EVALUATING THE EFFECT OF DIFFERENT LEVELS OF NITROGEN, PLANT POPULATION DENSITY, ROW SPACING AND IRRIGATION ON KENAF (Hibiscus cannabinus L.) FIBRE DEVELOPMENT
}

Kayembe P Kabeya ${ }^{1}$, Petrus J Robbertse ${ }^{1}$, Diana Marais ${ }^{1}$ \& J Martin Steyn ${ }^{1 *}$

Department of Plant and Soil Sciences, University of Pretoria, Private Bag X20, Hatfield 0028, Pretoria, South Africa.

${ }^{*}$ Corresponding author email: martin.steyn@up.ac.za

\section{Abstract}

Kenaf provides high quality fibre which is used in paper making, building materials and absorbents. The study aims were to conduct a proper anatomical study of fibre development in kenaf stems, and to investigate if the number of fibre wedges, fibre rings (layers) and fibre bundles can be used as a tool to determine fibre development response to different agronomic practices. The practices evaluated included different nitrogen levels $\left(0,50,100\right.$ and $\left.150 \mathrm{~kg} \mathrm{ha}^{-1} \mathrm{~N}\right)$ under both rainfed and irrigated conditions, as well as different combinations of plant population density $(300,000$, $400,000,500,000$ and 600,000 plants $\left.\mathrm{ha}^{-1}\right)$ and row spacing $(0.17,0.34$, and $0.50 \mathrm{~m})$ under rainfed conditions. In most cases $\mathrm{N}$, water, and plant population density were the principal factors affecting the number of fibre rings and fibre bundles, but not the number of fibre wedges. Higher levels of $\mathrm{N}$ and more water increased the number of fibre rings and fibre bundles, while at higher plant populations, these decreased. No 
clear trends were observed with regards to row spacing. The results of this study suggested that under local conditions, $150 \mathrm{~kg} \mathrm{ha}^{-1}$ of nitrogen applied in two splits, 300,000 plants per hectare and $0.50 \mathrm{~m}$ row spacing was the optimal combination of agronomic practices in terms of fibre development per plant. This paper gives a more complete explanation of fibre development in kenaf and shows how plant anatomy can be used as a tool to assess fibre development.

Keywords: Fibre wedges, fibre rings, fibre bundles, agronomic practices

\section{Introduction}

Kenaf is a fast-growing plant from the Malvaceae family (Hossain et al. 2011). Growing attention in kenaf has arisen from its potential to produce high quantities of biomass (stems and leaves), and high quality fibres in the stems for textiles, paper making, building materials and absorbents (Ramaswamy and Easter 1997, Webber et al. 2002, Chantiratikul et al. 2009, Shakhes et al. 2010). The stem of kenaf consists of an outer region namely bark or phloem and an inner region namely core, with a makeup respectively of about 40 and $60 \%$ of stem dry weight (Calamari et al. 1997, Tao et al. 1997, Chiaiese et al. 2011). Kenaf stems can grow up to 3 - 4 meters in length and $18-20 \mathrm{~mm}$ in basal diameter within four months and produce dry stem yields of about 40 tonnes per hectare, depending on the cultivar used, geographical conditions and agronomic practices (Kayembe 2015).

The core consists of the pith, without fibres and the xylem containing short and thick xylem fibres (Ververis et al. 2004) with lignified cell walls distributed amongst the vessel elements and parenchyma, while the phloem/bark fibres are much longer, running parallel to the length of the stem and the walls contain less lignin (Webber et 
al. 2002, Ververis et al. 2004, H'ng et al. 2009). According to Han et al. (1999) and Rashidi et al. (2009), kenaf phloem fibres are shorter at the bottom of the stem and longer at the top. Voulgaridis et al. (2000) gave figures of $2.40 \mu \mathrm{m}$ for the bottom, and $2.510 \mu \mathrm{m}$ for the top fibres. The individual fibre cells are grouped and 'cemented' together by pectins and lignin into fibre bundles (Ayre et al. 2009).

Several studies conducted on kenaf worldwide have been documented. Zhou et al. (1998) reported on selection of the optimal kenaf plant population density for papermaking raw material. Banüelos et al. (2002) discussed the vegetative production of kenaf under irrigation, while Agbaje et al. (2008) evaluated the influence of agronomic practices on yield and profitability in kenaf. Hossain et al. (2010) reported on the effects of nitrogen, phosphorus and potassium on kenaf growth and photosynthesis, while Sabharwal et al. (1994), Ogbonnaya et al. (1997), Ochi (2008), Ahmed et al. (2008) and Tahir et al. (2011) discussed the pulping of kenaf fibres. Maiti and Dagupta (1972) wrote a short communication on comparative microscopy of ten kenaf varieties, using the terms 'fibre wedges' and 'fibre layers' per wedge, but without statistical analysis of the data and no reference to the effects of agronomic practices. Maiti (1979) compared the fibre anatomy of different fibre plants based on transverse sections of the bottom parts of the stems only $(11.5 \mathrm{~cm}$ above the base). This author assessed the interconnection of bundles in the wedges, the number of fibre bundles in a wedge and the number of layers (rings) per wedge, but did not investigate the numbers of bundle layers per wedge in different parts of the stem. Maiti (1979) also did not relate these parameters to agronomic aspects. Abdul Khalil et al. (2010) concentrated on the thickness and chemical composition of the fibre cell walls of kenaf, but also did not investigate the influence of agronomic aspects such as fertilization, plant population density or irrigation. Voulgaridis et al. 
(2000) compared the lengths of kenaf fibre in the bottom, middle and top parts of the stems, but did not compare the number of bundles and layers of fibre bundles. Ayre et al. (2009) assessed the viscoelastic properties of kenaf bast fibres in relation to stem age and compared fibre bundles in sections $3.5 \mathrm{~cm}, 9 \mathrm{~cm}, 30 \mathrm{~cm}$ and $120 \mathrm{~cm}$ from the tip of $240 \mathrm{~cm}$ long kenaf stems grown under controlled conditions, but also did not study the influence of agronomic factors on fibre development. The latter authors also mentioned that fibre bundles are produced in rings, but erroneously referred to the first ring of phloem fibre bundles as 'primary phloem fibres' by ignoring the fibres outside the parenchymous primary phloem (Figure 1A), which are the true primary phloem fibres, as was reported by Maiti (1979) for ramie and flax. Maiti (1979) and Koning (1994) also referred to these fibres as 'pericycle fibres'. No reference was found that mentioned the presence of primary phloem fibres in kenaf stems or that explained how fibre bundle wedges are formed. Maiti (1979), referring to other authors, also posed the "not yet fully answered question, why different bast fibres vary in yield and quality".

From the literature cited above, it is clear that there is a need for a complete review of the anatomy of kenaf stems in order to get a better understanding of fibre development and to use anatomical criteria obtained from this study to evaluate the effect of different agronomic practices such as nitrogen level, plant population, row spacing and water level on bark fibre bundle development and fibre production, and to explain how fibre bundle wedges are formed.

\section{Materials and Methods}

Field trials were conducted on the Hatfield Experimental Farm of the University of

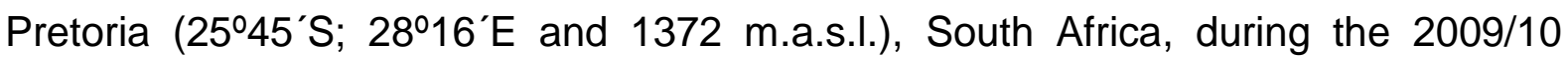


summer season. The soil of the experimental site was a sandy clay of the Hutton form. Field capacity (Fc) of the top $1.20 \mathrm{~m}$ soil layer was $266 \mathrm{~mm} \mathrm{~m}^{-1}$, with total plant available water (PAW) of $116 \mathrm{~mm} \mathrm{~m}^{-1}$ and an initial PAW at planting of $96 \mathrm{~mm} \mathrm{~m}^{-1}$ (Kayembe, 2015).

The site is situated in a summer rainfall region with an average annual rainfall of 670 $\mathrm{mm}$, mainly concentrated in the months of October to March, and monthly mean maximum and minimum temperatures of about $30^{\circ} \mathrm{C}$ in January and $1.5^{\circ} \mathrm{C}$ in July, respectively (Annandale et al. 1999). An automatic weather station situated $100 \mathrm{~m}$ from the experimental site was used to collect daily climate data such as rainfall, average wind speed, solar radiation, maximum and minimum temperatures, and maximum and minimum relative humidities.

Following the recommendation by Dempsey (1975) that kenaf can be grown in a wide range of soil types, from high organic peat soils to sandy desert soils, it can be assumed that the soil of the experimental site used in this study (properties summarised in Table 1) was suitable for kenaf growth.

Table 1. Soil chemical and physical characteristics of the topsoil $(0-25 \mathrm{~cm}$ depth) for fields before planting of the kenaf trials

\begin{tabular}{|c|c|c|c|c|c|c|c|c|c|}
\hline \multirow[t]{2}{*}{$\begin{array}{l}\mathrm{pH} \\
\left(\mathrm{H}_{2} \mathrm{O}\right)\end{array}$} & $\mathrm{NH}_{4}-\mathrm{N}$ & $\mathrm{NO}_{3}-\mathrm{N}$ & $P^{*}$ & $\mathrm{~K}^{\star \star}$ & $\mathrm{Ca}$ & $\mathrm{Mg}$ & $\mathrm{Na}$ & \multirow{2}{*}{$\begin{array}{l}\text { Bulk } \\
\text { density } \\
\left(\mathrm{kg} \mathrm{m}^{-3}\right)\end{array}$} & \multirow{2}{*}{$\begin{array}{l}\text { Clay } \\
\text { content } \\
(\%)\end{array}$} \\
\hline & & & & $\left(\mathrm{mg} \mathrm{kg}^{-1}\right.$ & & & & & \\
\hline 5.93 & 39.1 & 43.9 & 24.3 & 50.3 & 471.7 & 118.7 & 49.3 & 1500 & 17.9 \\
\hline
\end{tabular}

Notes: *Bray $1 ;{ }^{* *}$ Ammonium acetate extraction method used for cations

The monthly climate data over the study period between 1 December 2009 and 30 April 2010 are presented in Table 2. Since kenaf is a warm weather crop (Fike 1990, Webber et al. 2016), it can be assumed that the weather conditions experienced 
during the $2009 / 10$ summer growing season was suitable for kenaf. The rainfall was also sufficient to sustain kenaf growth, but supplementary irrigation was applied to the irrigated $\mathrm{N}$ trial to ensure optimal growth conditions.

Table 2. Monthly weather data for the $2009 / 10$ growing season, including mean maximum (Tx) and

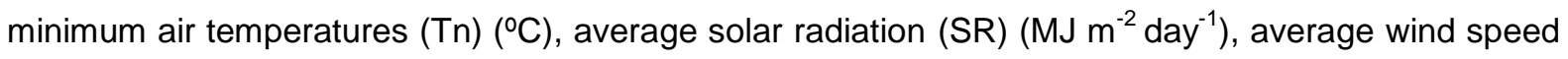
(WS) $\left(\mathrm{m} \mathrm{s}^{-1}\right)$, maximum $(\mathrm{RHx})$ and minimum relative humidities $(\mathrm{RHn})(\%)$, total monthly rainfall $(\mathrm{mm})$ and irrigation amounts $(\mathrm{mm})$ for the irrigation trial

\begin{tabular}{|c|c|c|c|c|c|}
\hline \multirow[b]{2}{*}{ Parameter } & \multicolumn{5}{|c|}{ Month } \\
\hline & December & January & February & March & April \\
\hline Tx & 28.9 & 28.4 & 29.8 & 29.3 & 23.5 \\
\hline Tn & 15.6 & 17.3 & 16.3 & 15.5 & 8.5 \\
\hline SR & 18.5 & 15.1 & 17.2 & 15.2 & 10.9 \\
\hline $\mathrm{RHx}$ & 87 & 89 & 87 & 88 & 89 \\
\hline $\mathrm{RHn}$ & 39 & 44 & 34 & 33 & 33 \\
\hline WS & 1.84 & 1.63 & 1.54 & 1.31 & 1.06 \\
\hline Rainfall & 129 & 111 & 74 & 32 & 54 \\
\hline Irrigation & 25 & 98 & 153 & 220 & 164 \\
\hline
\end{tabular}

The photosensitive kenaf cultivar Tainung 2 was used and two nitrogen trials were conducted, one under rainfed conditions and a second under full irrigation. Another trial was conducted to investigate the combination of plant population density and row spacing effects under rainfed conditions on fibre production. Both nitrogen trials were planted at a population density of 500,000 plants ha $^{-1}$. The plants were grown in $3.5 \times 4 \mathrm{~m}^{2}$ plots comprising eight rows planted $0.50 \mathrm{~m}$ apart, in a completely randomised block design (CRBD) with four replicates. Four nitrogen levels $\left(0 \mathrm{~kg} \mathrm{ha}^{-1}\right.$, $50 \mathrm{~kg} \mathrm{ha}^{-1}, 100 \mathrm{~kg} \mathrm{ha}^{-1}$, and $150 \mathrm{~kg} \mathrm{ha}^{-1} \mathrm{~N}$ ) were applied. Nitrogen was applied in two 
dressings so that each plot received 0 or $50 \mathrm{~kg} \mathrm{ha}^{-1} \mathrm{~N}$ at planting and 0,50 or $100 \mathrm{~kg}$ $\mathrm{ha}^{-1} \mathrm{~N}$ after thinning (35 days after planting, DAP).

The plant population density and row spacing trial was laid out in a split-plot experimental design with treatments arranged in a CRBD. Plant populations $\left(300,000\right.$ plants ha ${ }^{-1}, 400,000$ plants $\mathrm{ha}^{-1}, 500,000$ plants ha $^{-1}$ and 600,000 plants ha $\left.{ }^{1}\right)$ were allocated to the main plots, while the sub-plots $\left(3.5 \times 4 \mathrm{~m}^{2}\right.$ in size) were devoted to the row spacing treatments of $0.17 \mathrm{~m}, 0.34 \mathrm{~m}$ and $0.50 \mathrm{~m}$. Each treatment combination was replicated four times. Nitrogen was applied at a rate of $150 \mathrm{~kg} \mathrm{ha}^{-1} \mathrm{~N}$, of which $50 \mathrm{~kg} \mathrm{ha}^{-1} \mathrm{~N}$ was applied at planting and $100 \mathrm{~kg} \mathrm{ha}^{-1} \mathrm{~N}$ after thinning (35 DAP). In order to ensure optimum growth conditions, $100 \mathrm{~kg} \mathrm{ha}^{-1}$ potassium and $30 \mathrm{~kg} \mathrm{ha}^{-1}$ phosphorus were applied at planting to the entire experimental site. During the winter season preceding the kenaf trial, the entire trial site was planted to wheat without any NPK fertiliser added in an effort to deplete any residual nutrients from the soil. All plots and sub-plots were kept weed free by hand weeding throughout the trial period. No incidence of insects or diseases was observed during the growing season.

A neutron probe (Hydroprobe $\AA$, Model 503 DR, CA, USA) was calibrated for the trial site and used to monitor soil water content of the upper $1.20 \mathrm{~m}$ soil profile for the nitrogen trials only. A neutron probe access tube was installed in the middle of each plot. To ensure optimum soil water content for good crop emergence, $25 \mathrm{~mm}$ of water was applied directly after planting to both nitrogen trials and the plant population density and row spacing trial using an overhead sprinkler irrigation system. Thereafter, another $25 \mathrm{~mm}$ of irrigation was applied at thinning (35 DAP) to the rainfed nitrogen trial only. A drip irrigation system was installed for the irrigated nitrogen trial. One dripper line was placed between two adjacent plant rows, giving a 
total of seven dripper lines per plot. Each of the dripper lines had 12 emitters spaced $0.3 \mathrm{~m}$ apart with an average drip rate of $2.175 \mathrm{~L} \mathrm{~h}^{-1}$. The water flow to each plot was controlled by an individual valve. Irrigation was managed using an Excel-based calculator which combined meteorological, soil and plant data to calculate the deficit to Fc. The trial was irrigated weekly by refilling the soil profile to field capacity, starting from 23 DAP until the end of the growing season. Rainfall and sprinkler irrigation were monitored using manual rain gauges. A soil ridge was made at the border of each plot to avoid the lateral flow of water onto plots.

Plants were harvested at 96, 104 and 108 days after planting (DAP) for the irrigated, rainfed, and plant population/row spacing trials, respectively. Four plants were randomly harvested from the middle of each plot or each sub-plot by cutting off the stems at ground level. The leaves were removed and the stem height of each plant was measured from the cutting point to the tip of the stem. Four stem segments of 2 $\mathrm{cm}$ each were cut from three different positions; bottom, middle and two top sections of each stem after removing the $10 \mathrm{~cm}$ apical part containing undifferentiated tissues. Similar approaches were previously used by Paraskevopoulou (1987) and Ververis et al. (2004). Thereafter the diameter of each segment was measured using a digital calliper. The segments were taken to the plant anatomy laboratory of the Department of Plant and Soil Sciences at the University of Pretoria, where they were fixed and stored in Formaldehyde Acetic Acid (FAA) solution (Jensen 1962) until the day of microscopic analysis. A hand-cut cross-section of approximately $0.02 \mathrm{~mm}$ thick was made from each segment using a sharp blade. Sections were stained with 1\% toluidine blue (O'Brien and McCully 1981) and phloroglucinol (Jensen 1962), rinsed with tap water and mounted in glycerol. The sections were then examined by means of a light transmission microscope (Leitz) fitted with a digital camera to 
assess fibre development. During the sectioning care was taken to cut a uniform disc from the proximal end of each segment. For the bottom segment, the sections contained at least a fourth of the total stem cross-sectional surface, while for the middle segment the sections contained about one half, and for the top segment the complete cross-sectional surface of the stem was used. The number of fibre wedges, fibre rings, and fibre bundles in each section were then counted and photographed.

All the data were analysed using analyses of variances (ANOVA) with the GLM procedures of SAS $\left(\right.$ SAS $^{\circledR}$ Institute, Inc., 2002-2010, 9.3 Software) to assess treatment differences. Any measured trait was considered significantly affected if $P<0.05$, or highly significant if $P<0.01$, and not significant if $P \geq 0.05$. Mean separation was done using Tukey's Honestly Significant Difference (HSD) test at $P=0.05$.

\section{Results}

\section{Kenaf stem anatomy}

Only procambium strands are present in cross sections below and close to the apical meristem of the kenaf stem. The primary phloem elements differentiate from the outer cells of the procambium and the primary xylem from the inner cells. The remaining layer of procambium cells between the primary phloem and xylem remains meristematic and becomes the vascular cambium (Raven et al. 1992). The outer primary phloem cells develop into primary phloem fibres (Figure $1 \mathrm{~A}$ ). As soon as the vascular cambium cells start dividing, secondary xylem and secondary phloem, including the secondary phloem fibre bundles, are produced by the vascular cambium. In kenaf, the commercial phloem fibres, therefore, consist entirely of secondary fibres produced by the vascular cambium as part of the secondary 


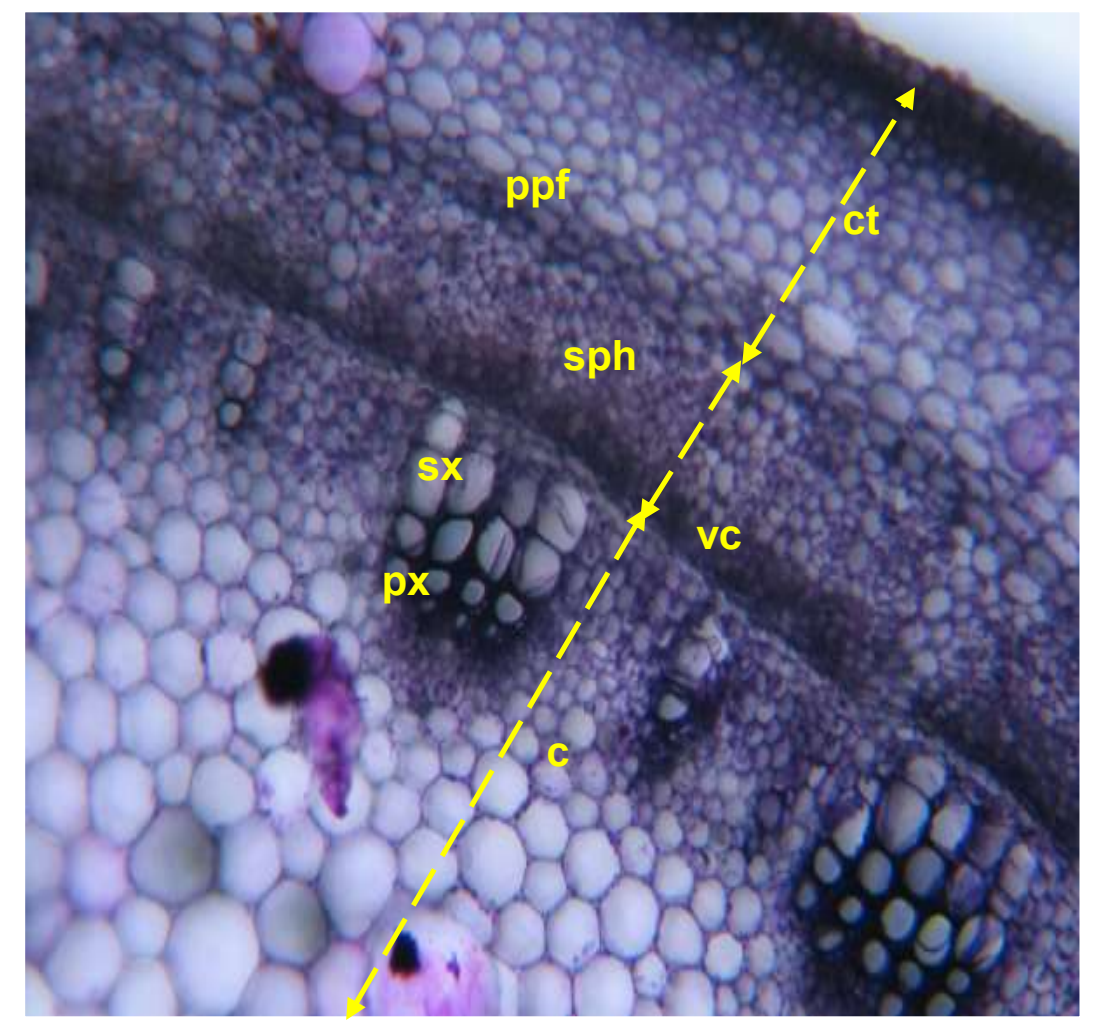

Figure 1A. Cross section of top kenaf stem segment stained with toluidine blue; $c=c o r e, c t=c o r t e x, p p f=p r i m a r y$ phloem fibres, $\mathrm{px}=$ primary $\mathrm{xylem}, \mathrm{sx}=$ secondary $\mathrm{xylem}, \mathrm{sph}=\mathrm{secondary}$ phloem, $\mathrm{vc}=$ vascular cambium

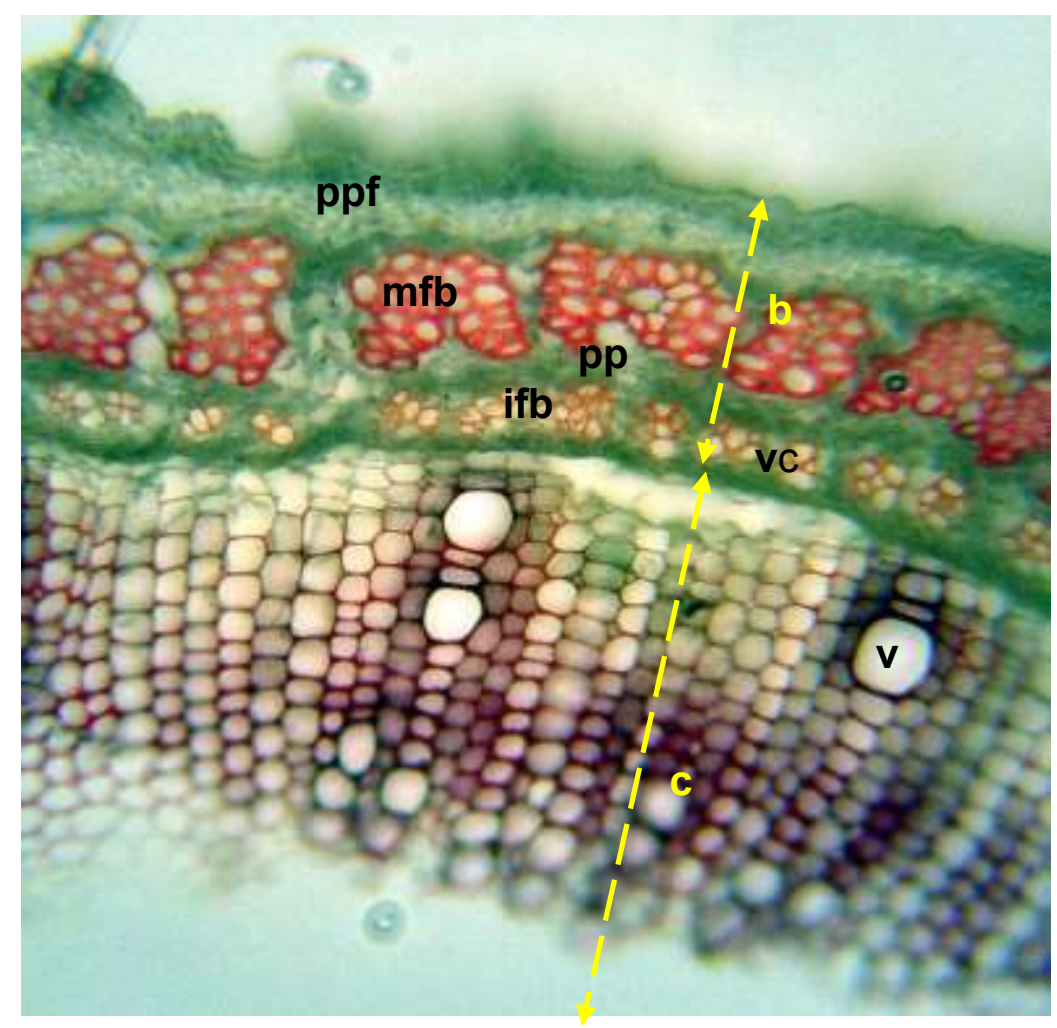

Figure 1B. Cross section of top kenaf stem segment stained with phloroglucinol; $b=b a r k, c=c o r e$, ifb $=$ immature secondary fibre bundles, $\mathrm{mfb}=$ mature secondary fibre bundles, $\mathrm{pp}=$ phloem parenchyma, $\mathrm{ppf}=$ primary phloem fibres, $v=$ vessel element, $v c=$ vascular cambium 


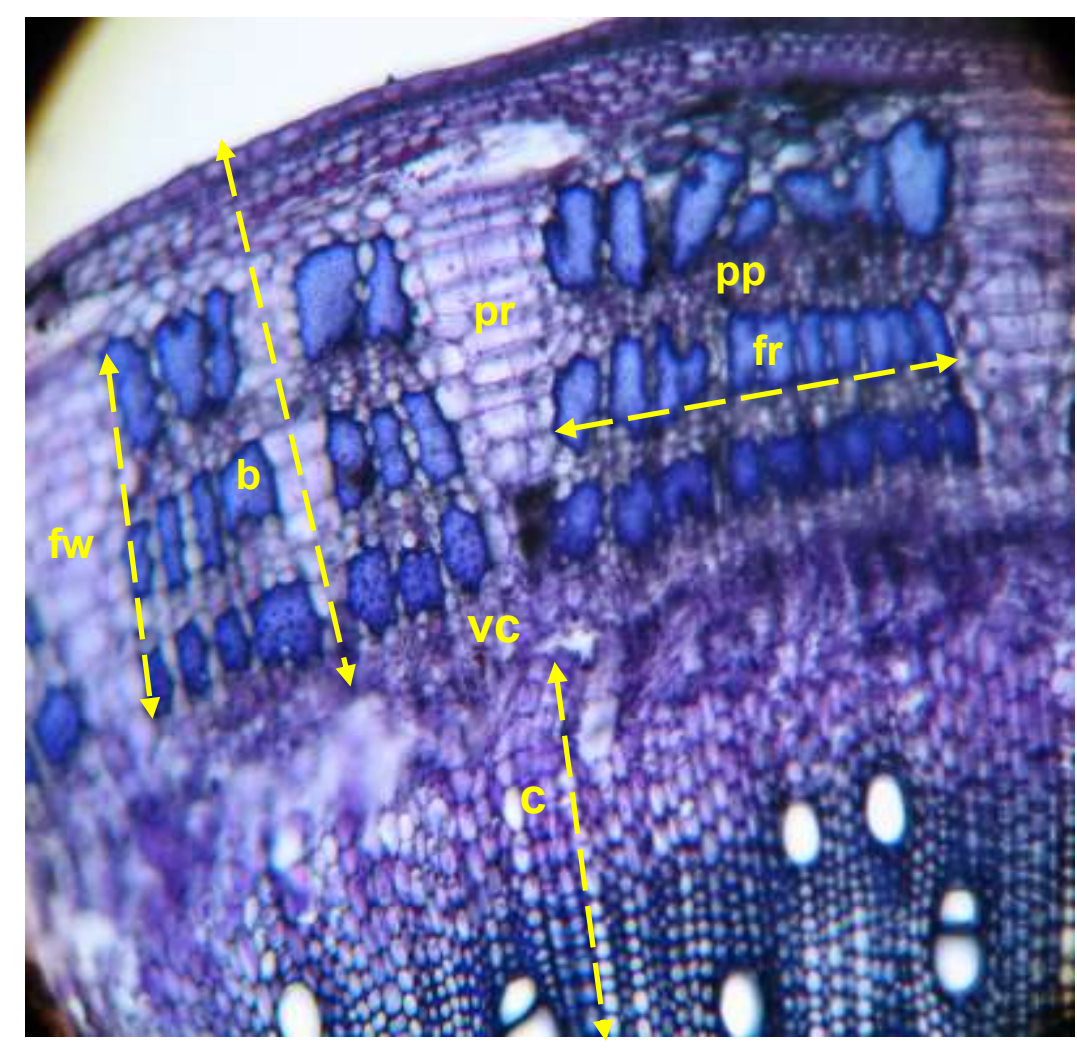

Figure 2A. Cross section through the middle segment of a kenaf stem stained with toluidine blue, showing clear fibre wedges; $b=b a r k, c=c o r e, f r=$ fibre rings, $\mathrm{fw}=$ fibre wedges, $\mathrm{pp}=$ phloem parenchyma, $\mathrm{pr}=$ phloem rays, $\mathrm{vc}=$ vascular cambium

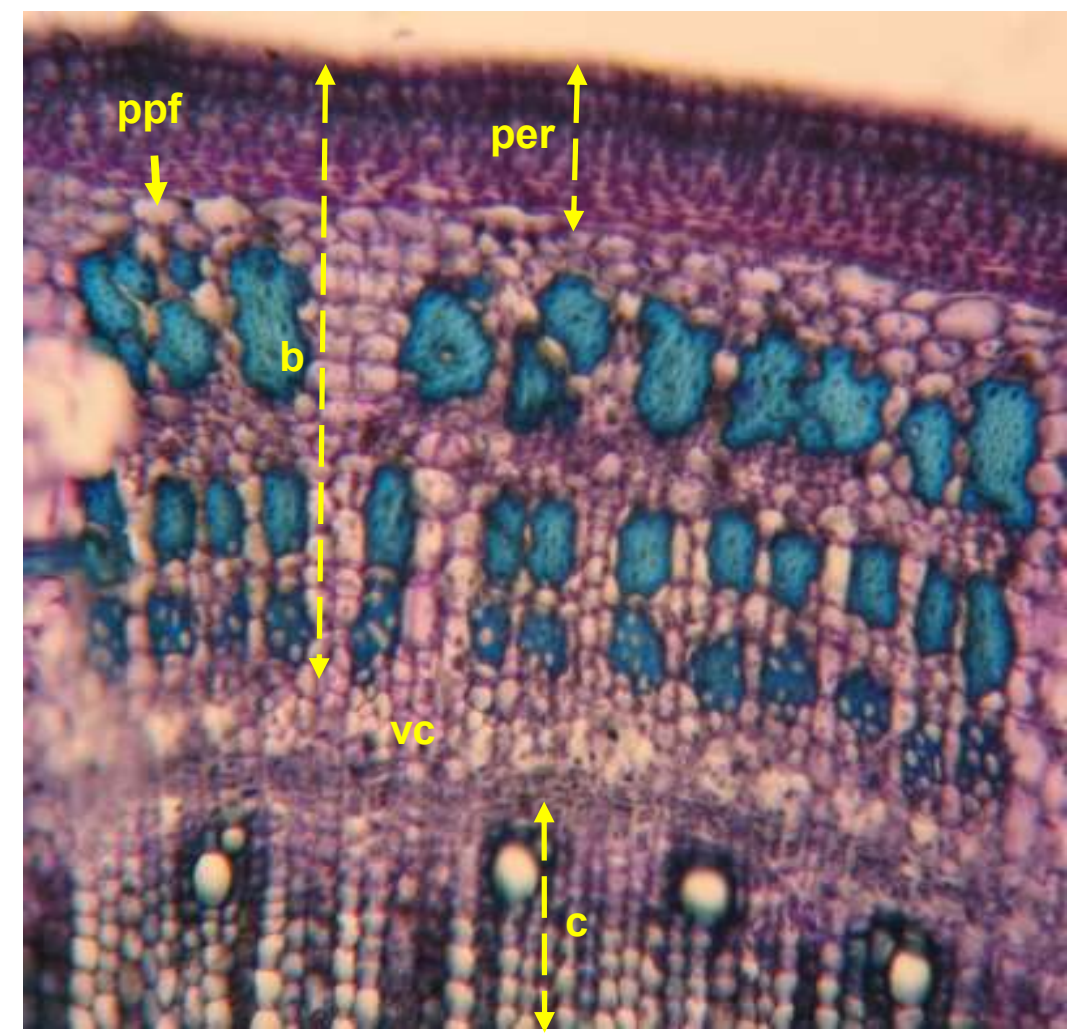

Figure 2B. Cross section through the middle segment of a kenaf stem stained with toluidine blue, with no clear fibre wedges; $b=$ bark, $c=$ core, per $=$ periderm, $p p f=$ primary phloem fibres, $v c=$ vascular cambium 


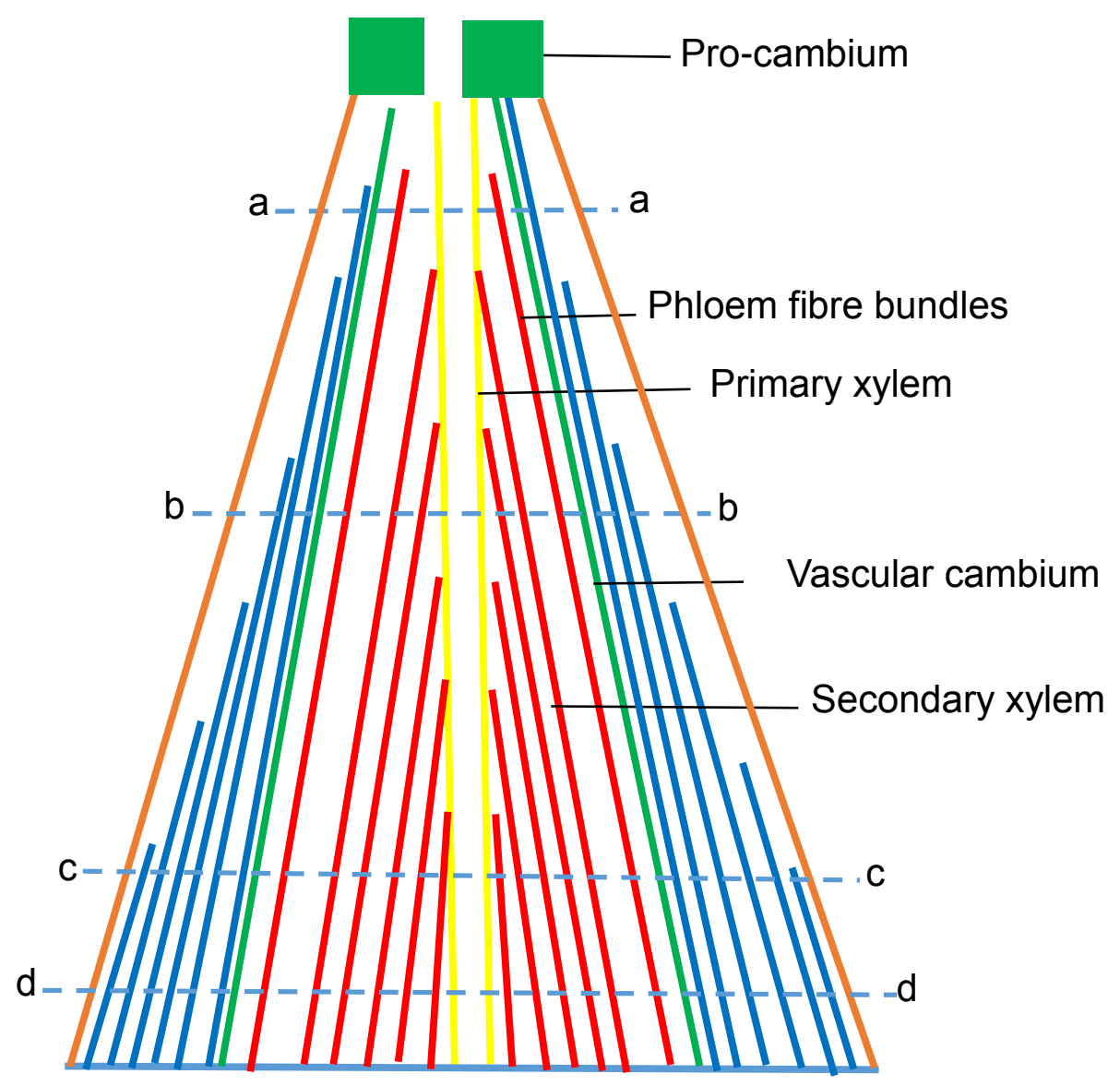

Figure 3A. Simplified diagram of a longitudinal section of a kenaf stem, excluding the apical dome, cortex and epidermis, showing a primary and secondary xylem and phloem. Labelled dotted lines refer to the positions where sections were made for Figures 1, 2 and 3 B. 


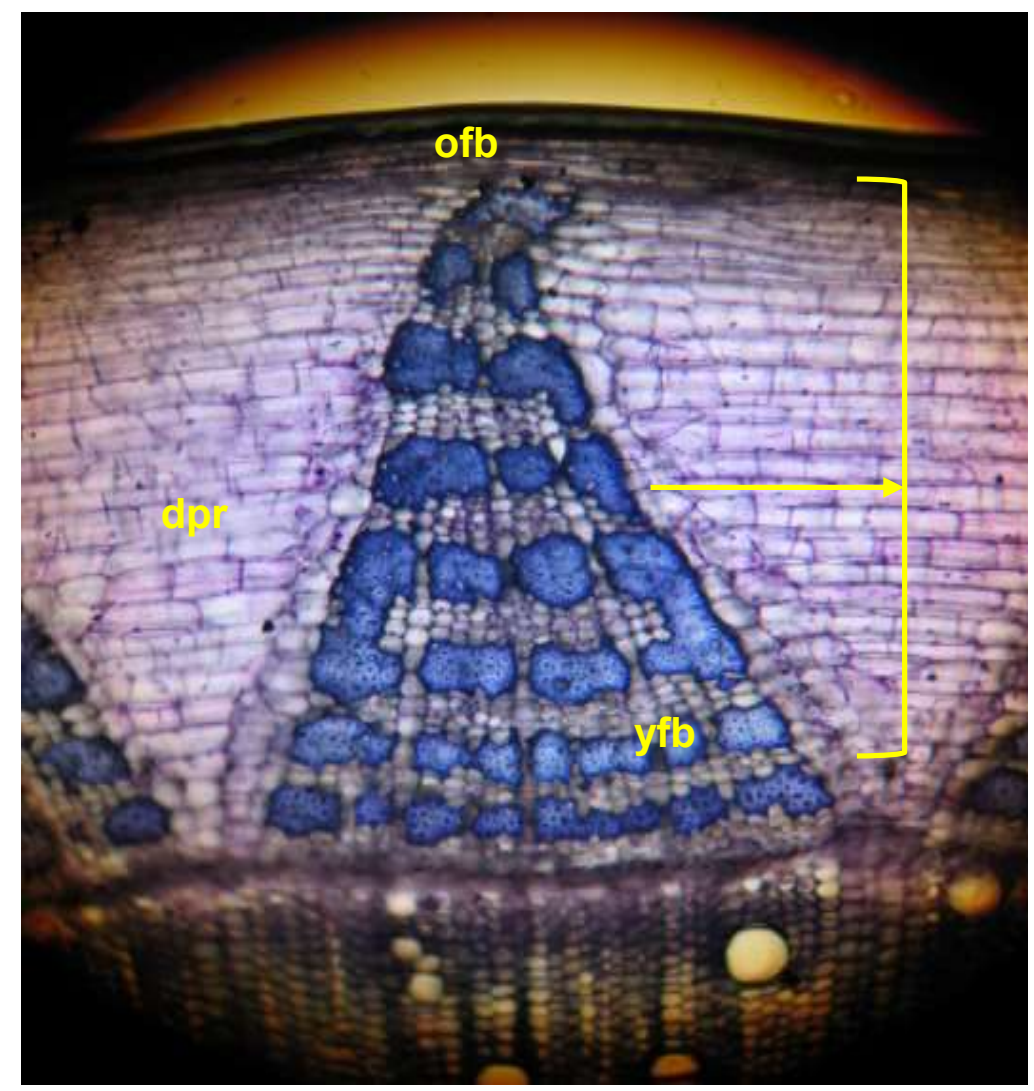

Figure 3B. Cross section through the bottom segment of the stem; dpr= dilated phloem ray consisting of phloem parenchyma separating fibre wedges, ofb= oldest ring of fibre bundles in fibre bundle wedge, yfb=youngest fibre bundles in fibre bundle wedge

phloem and are grouped together in separate bundles. These bundles of fibres are produced alternately, with thin-walled functional phloem elements (Figures $1 \mathrm{~A}$ and 1B) and the result is that the fibre bundles occur in successive concentric rings, but also in radial rows separated by phloem ray parenchyma (Figures $1 \mathrm{~B}, 2 \mathrm{~A}$ and $2 \mathrm{~B}$, and $3 \mathrm{~B})$. As a result of the dilation of some phloem rays, parenchymatous wedges are formed that separate groups of fibre bundles from successive rings into uneven, inverted triangular or wedge-shaped bundles, referred to as fibre wedges (Figure 2A and $3 \mathrm{~B})$. As illustrated in Figure $3 \mathrm{~A}$ and when comparing Figures $1 \mathrm{~A}, 1 \mathrm{~B}, 2 \mathrm{~B}$ and $3 \mathrm{~B}$, the number of concentric fibre bundle rings decreases from the base of the stem to the apex. The reason being that every new fibre bundle ring is produced inside the previous ring, as shown in Figure $3 \mathrm{~A}$. Figure $1 \mathrm{~A}$ shows a section of a stem 
(corresponding with line a-a in Figure $3 \mathrm{~A}$ ), taken from where secondary growth had just started. Figure 1B shows a section of the top segment with one ring of differentiated fibre bundles and a second ring inside the first and adjacent to the vascular cambium, with fibre bundles still differentiating (corresponding with line $b-b$ in Figure $3 \mathrm{~A}$ ). Three fibre bundle rings are shown in Figure $2 \mathrm{~A}$ and $\mathrm{B}$ (line $\mathrm{C}-\mathrm{c}$ in Figure $3 A$ ). Figure $3 B$, from a section of the bottom part of the stem (line $d-d$ in Figure $3 \mathrm{~A}$ ), shows a fibre bundle wedge containing eight bundle layers derived from concentric fibre bundle rings. The fibre bundles of the outer (first-formed) rings have been pushed apart by the dilating phloem rays.

The outer fibre bundles (oldest) are shorter and the inner ones (youngest) are longer as a result of secondary growth and sequential formation of fibre bundle rings (Figure $3 \mathrm{~A}$ ). Within the fibre wedges the fibre bundles are arranged in tangential rows (layers according to Maiti and Dagupta 1972), while individual bundles are separated from each other tangentially by thin-walled axial phloem parenchyma, and radially by phloem ray parenchyma (Figures $2 \mathrm{~A}$ and $2 \mathrm{~B}$ ). The fibre bundles are therefore, surrounded by thin-walled parenchyma cells (Figure 4B), which are 'digested' during the retting process (the separation of fibre bundles from other tissues and is based on the differential degradation of fibre and non-fibre cells) (Ayre et al. 2009 and Figures 5A and 5B). Maiti (1979) mentioned that "the fiber strands thus formed are connected here and there along their longitudinal course to form a meshy structure of bast fibers". However, it is actually also the fibre wedges that merge and split to form a network as seen in a tangential section of the basal parts of the stem, similar to a tangential section of a woody stem. 


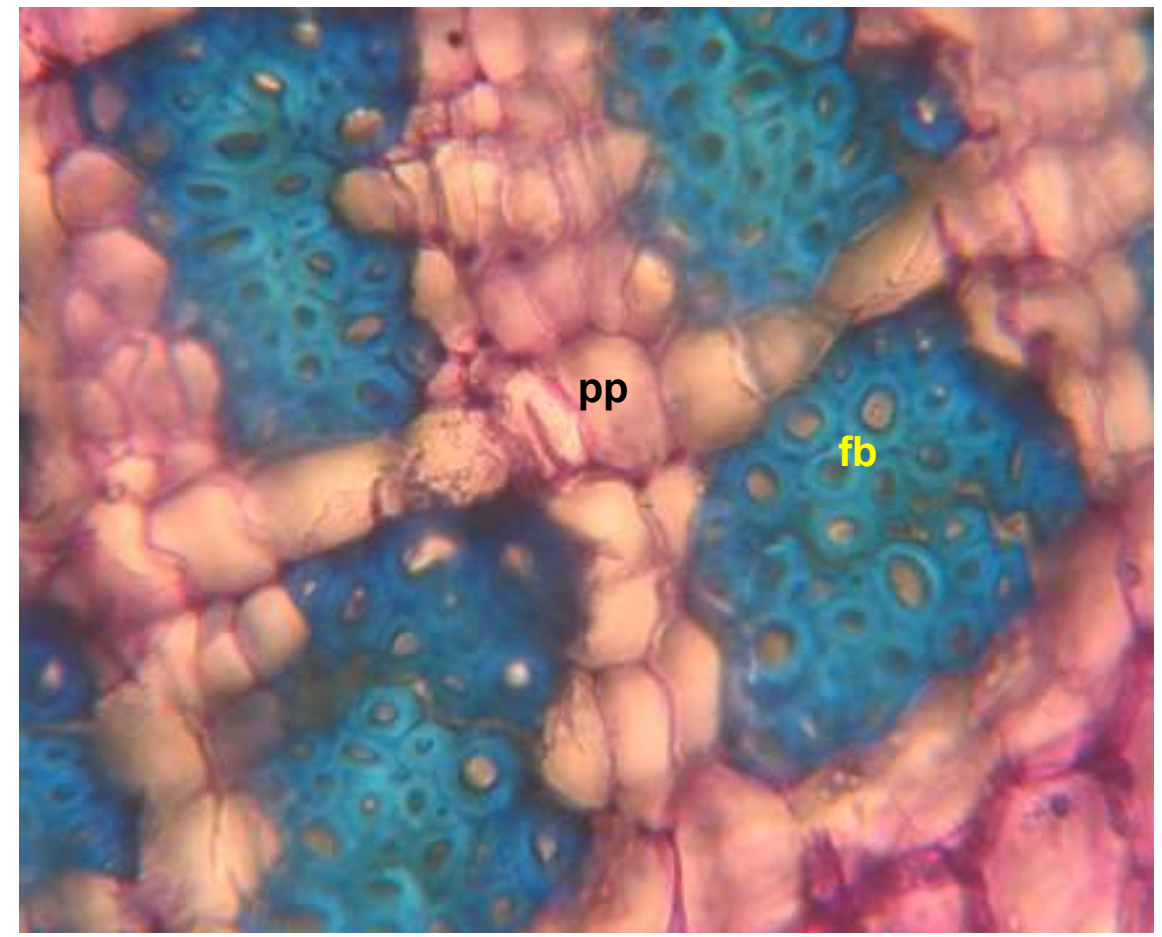

Figure 4A. Section of kenaf fibre bundles stained with toluidine blue; $\mathrm{fb}=$ fibre bundles, $\mathrm{pp}=\mathrm{phloem}$ parenchyma

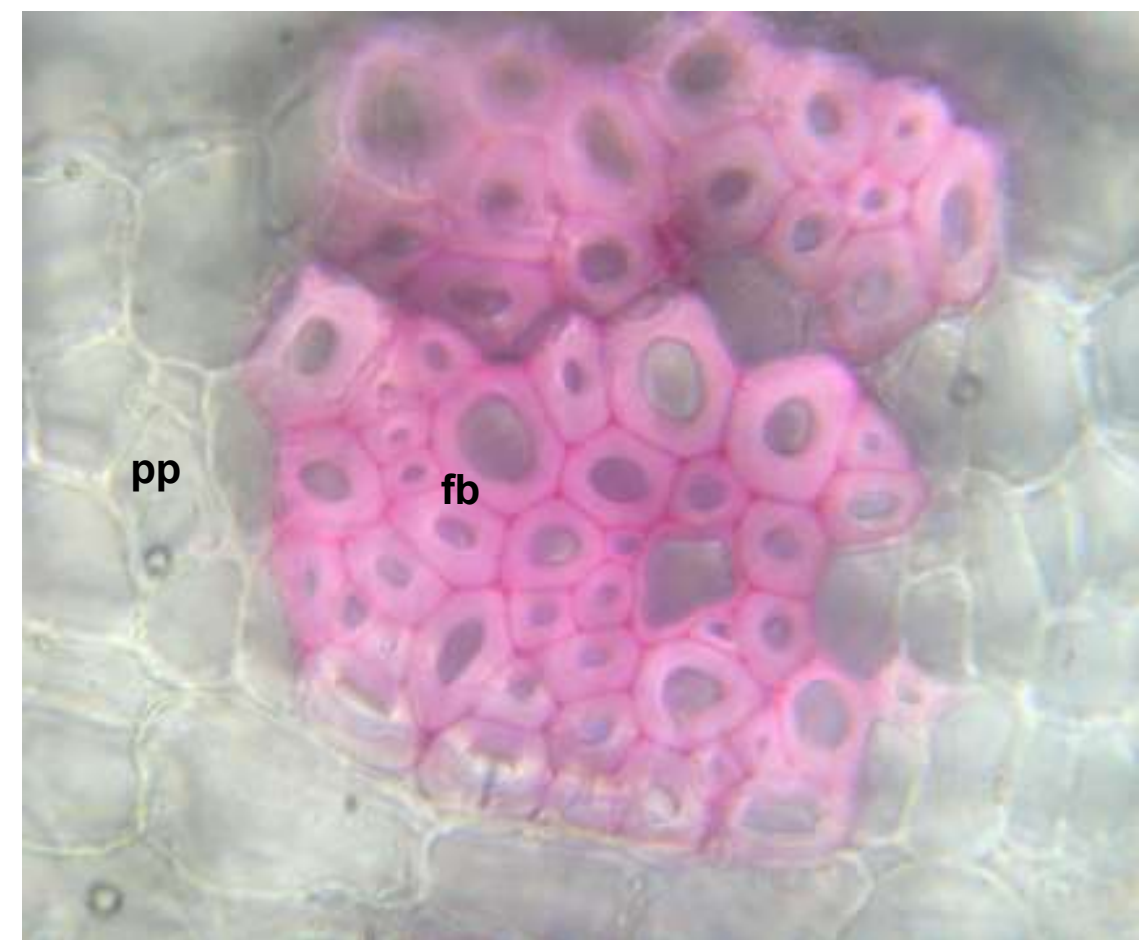

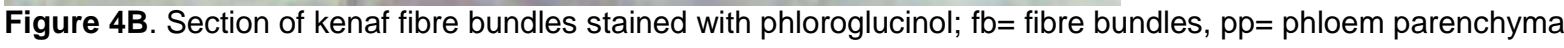




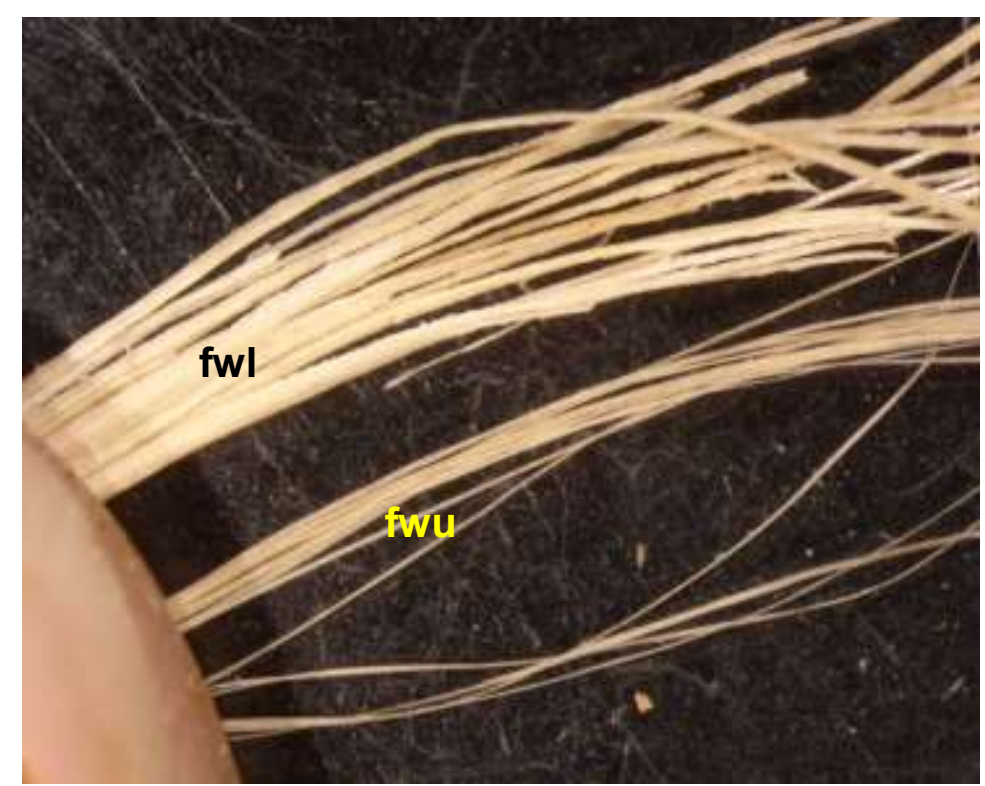

Figure 5A. Fibre bundles after different stages of retting; two partly retted fibre wedges, one from the bottom section (fwl), and one from the top section (fwu)

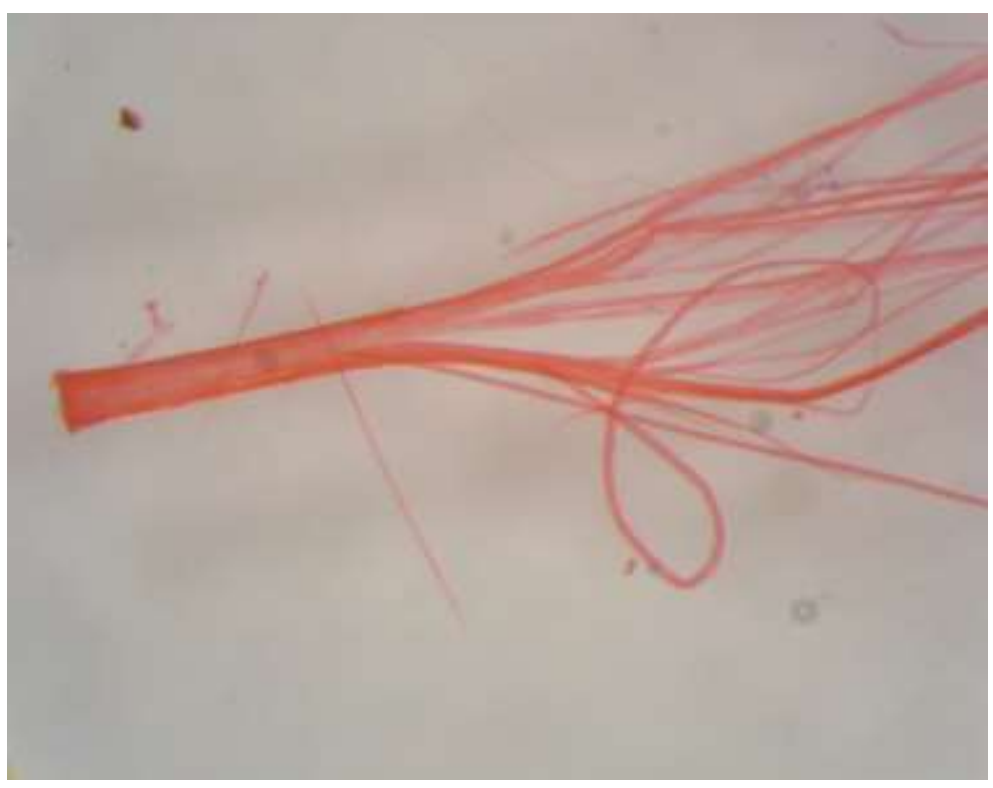

Figure 5B. Fibre bundles after different stages of retting with retted single fibre bundle splitting up into fibre cells

Since the individual fibre cells in the bundles are glued together by the middle lamella containing hemicellulose and pectose (Mati 1979) as well as lignin (Abdul et al. 2009), they stay together during retting (Figure 5A), although over-retting will cause separation of individual fibre cells (Figure 5B). The lignin in the fibre cell walls reacted positively after staining with toluidine blue (turquoise) and phloroglucinol 
(red) (Figures 4A and 4B), while the primary phloem fibres (Figure 1B) with cellulose walls like the surrounding parenchyma (Figure 4B), did not stain.

\section{Effect of different agronomic practices on stem height, thickness (diameter) of segments and fibre development}

The number of fibre wedges, fibre rings and fibre bundles were used as criteria to compare the effect of different agronomic practices on fibre development. From the results it appeared that the number of fibre wedges did not show any clear trend in reaction to the different treatments. Therefore, only the number of fibre rings (fibre bundle layers in the wedges) and total number of fibre bundles per section were used as anatomical criteria for further discussion.

\section{Stem height and thickness}

Compared with the control, stem height and stem thickness (diameter) of the top, middle and bottom segments increased significantly $(P<0.01, P<0.05)$ in response to increasing nitrogen $(\mathrm{N})$ level under both rainfed and irrigation conditions (Table 3 ). 
Table 3. Effect of nitrogen level on stem height and segment thickness (diameter) for different stem segments (top, middle and bottom) under rainfed and irrigation conditions

\begin{tabular}{|c|c|c|c|c|}
\hline \multirow{2}{*}{$\begin{array}{l}\text { Nitrogen level } \\
\left(\mathrm{kg} \mathrm{h}^{-1}\right)\end{array}$} & \multirow{2}{*}{$\begin{array}{l}\text { Stem height } \\
(\mathrm{cm})\end{array}$} & \multicolumn{3}{|c|}{ Segment thickness (diameter) $(\mathrm{mm})$} \\
\hline & & Top & Middle & Bottom \\
\hline \multicolumn{5}{|c|}{ Rainfed } \\
\hline 0 & $194.2 b$ & $5.2 b$ & $7.0 \mathrm{~b}$ & $12.3 b$ \\
\hline 50 & $200.3 b$ & $6.1 \mathrm{ab}$ & $6.6 \mathrm{~b}$ & $13.1 \mathrm{ab}$ \\
\hline 100 & $237.2 \mathrm{a}$ & $6.4 \mathrm{a}$ & $8.9 \mathrm{a}$ & $14.1 \mathrm{ab}$ \\
\hline 150 & $245 a$ & $7.0 \mathrm{a}$ & $9.7 \mathrm{a}$ & $14.9 \mathrm{a}$ \\
\hline Mean & 218.2 & 6.2 & 8.0 & 13.6 \\
\hline CV (\%) & 3.8 & 8.1 & 6.0 & 6.1 \\
\hline $\mathrm{p}$-value & $<0.0001$ & 0.0043 & $<0.0001$ & 0.0092 \\
\hline HSD & 18.2 & 1.1 & 1.1 & 1.8 \\
\hline \multicolumn{5}{|c|}{ Irrigation } \\
\hline 0 & $192.1 \mathrm{c}$ & $5.9 \mathrm{~b}$ & $9.9 \mathrm{~b}$ & $12.9 \mathrm{~b}$ \\
\hline 50 & $223.1 \mathrm{~b}$ & $6.3 a b$ & $14.4 \mathrm{a}$ & $14.1 \mathrm{ab}$ \\
\hline 100 & $241.8 \mathrm{a}$ & $7.2 \mathrm{ab}$ & $11.8 \mathrm{ab}$ & $15.4 \mathrm{a}$ \\
\hline 150 & $258.2 \mathrm{a}$ & $7.5 \mathrm{a}$ & $13.4 \mathrm{a}$ & $15.8 \mathrm{a}$ \\
\hline Mean & 228.8 & 6.7 & 12.3 & 14.5 \\
\hline CV $(\%)$ & 3.6 & 10.0 & 12.3 & 5.7 \\
\hline $\mathrm{p}$-value & $<0.0001$ & 0.0203 & 0.0097 & 0.0033 \\
\hline HSD & 18.3 & 1.5 & 3.3 & 1.8 \\
\hline
\end{tabular}

HSD: Tukey's Honestly Significant Difference to separate means. Means within the same column followed by the same letter are not significantly different

Opposite to the response to increasing $\mathrm{N}$ level, stem height and the thickness of different stem segments decreased significantly $(P<0.01)$ with an increase in plant population density from 300,000 plants $\mathrm{ha}^{-1}$ to 600,000 plants ha $^{-1}$ (Table 4). Row spacing had a significant effect $(P<0.01, P<0.05)$ on the thickness of the bottom and top segments only (Table 4), with thinner stems at narrower spacings. Stem height 
and thickness of the middle segments were not significantly affected by an increase in row spacing (Table 4). Neither stem height nor the thickness of segments was significantly affected by the interaction of plant population density and row spacing.

Table 4. Effect of plant population density and row spacing on stem height and segment thickness (diameter) for different stem segments (top, middle and bottom) under rainfed conditions

\begin{tabular}{|c|c|c|c|c|}
\hline \multirow{2}{*}{$\begin{array}{l}\text { Plant population } \\
\text { (plants ha }^{-1} \text { ) }\end{array}$} & \multirow{2}{*}{ Stem height $(\mathrm{cm})$} & \multicolumn{3}{|c|}{$\begin{array}{l}\text { Segment thickness } \\
\text { (diameter) }(\mathrm{mm})\end{array}$} \\
\hline & & Top & Middle & Bottom \\
\hline 300,000 & $244.7 \mathrm{a}$ & $6.8 \mathrm{a}$ & $10.9 \mathrm{a}$ & $15.0 \mathrm{a}$ \\
\hline 400,000 & $234.2 b$ & $6.0 \mathrm{a}$ & $10.1 \mathrm{~b}$ & $14.3 a b$ \\
\hline 500,000 & $229.0 \mathrm{~b}$ & $4.7 \mathrm{~b}$ & $9.8 \mathrm{~b}$ & $14.0 \mathrm{~b}$ \\
\hline 600,000 & $219.9 c$ & $4.7 \mathrm{~b}$ & $9.8 \mathrm{~b}$ & $13.9 \mathrm{~b}$ \\
\hline Mean & 232.0 & 5.6 & 10.1 & 14.3 \\
\hline CV (\%) & 4.6 & 11.9 & 7.7 & 4.3 \\
\hline$p$-value & $<0.0001$ & $<0.0001$ & 0.0048 & 0.0011 \\
\hline HSD & 8.32 & 0.97 & 0.76 & 0.97 \\
\hline \multicolumn{5}{|l|}{ Row spacing (m) } \\
\hline 0.17 & $232.3 \mathrm{a}$ & $5.2 b$ & $9.9 \mathrm{a}$ & $13.7 b$ \\
\hline 0.34 & $232.3 a$ & $5.7 \mathrm{ab}$ & $10.4 \mathrm{a}$ & $14.4 \mathrm{a}$ \\
\hline 0.50 & $234.3 \mathrm{a}$ & $5.9 \mathrm{a}$ & $10.2 \mathrm{a}$ & $14.7 \mathrm{a}$ \\
\hline Mean & 232.0 & 5.6 & 10.1 & 14.3 \\
\hline CV (\%) & 4.6 & 11.9 & 7.7 & 4.3 \\
\hline$p$-value & 0.4406 & 0.0232 & 0.2129 & 0.0005 \\
\hline HSD & - & 0.58 & - & 0.97 \\
\hline \multicolumn{5}{|l|}{ Plant pop x RS } \\
\hline Mean & 232.0 & 5.6 & 10.1 & 14.3 \\
\hline CV (\%) & 4.6 & 11.9 & 7.7 & 4.3 \\
\hline$p$-value & 0.610 & 0.043 & 0.654 & 0.480 \\
\hline HSD & - & 1.71 & - & - \\
\hline
\end{tabular}

HSD: Tukey's Honestly Significant Difference to separate means. Means within the same column followed by the same letter are not significantly different 


\section{Fibre development under rainfed and irrigation conditions}

In spite of a positive trend, nitrogen levels had no significant effect on the number of fibre rings in any of the three sections of stems grown under rainfed conditions (Table 5). There was, however, a significant increase in the number of fibre rings (layers in wedges) of the bottom $(P<0.01)$ and middle stem segments $(P<0.05)$ with increasing nitrogen level under irrigation (Table 5). An increase in nitrogen level also significantly increased the total number of fibre bundles per section of all stem segments under both rainfed and irrigation conditions (Table 6).

Table 5. Effect of nitrogen level on the number of fibre rings for different stem segments (top, middle and bottom) under rainfed and irrigation conditions

\begin{tabular}{|c|c|c|c|c|c|c|}
\hline \multirow{2}{*}{$\begin{array}{l}\text { Nitrogen } \\
\text { level }\left(\mathrm{kg} \mathrm{ha}^{-1}\right)\end{array}$} & \multicolumn{3}{|c|}{ Rainfed } & \multicolumn{3}{|c|}{ Irrigation } \\
\hline & Top & Middle & Bottom & Top & Middle & Bottom \\
\hline 0 & $1.0 \mathrm{a}$ & $3.0 \mathrm{a}$ & $7.76 \mathrm{a}$ & $1.06 \mathrm{a}$ & $3.13 b$ & $7.78 \mathrm{~b}$ \\
\hline 50 & $1.24 \mathrm{a}$ & $2.94 \mathrm{a}$ & $7.84 \mathrm{a}$ & $1.23 \mathrm{a}$ & $3.29 a b$ & $7.83 \mathrm{~b}$ \\
\hline 100 & $1.19 \mathrm{a}$ & $3.10 \mathrm{a}$ & $7.80 \mathrm{a}$ & $1.19 \mathrm{a}$ & $3.36 \mathrm{ab}$ & $7.98 \mathrm{~b}$ \\
\hline 150 & $1.35 \mathrm{a}$ & $3.25 \mathrm{a}$ & $7.95 \mathrm{a}$ & $1.30 \mathrm{a}$ & $3.50 \mathrm{a}$ & $9.13 \mathrm{a}$ \\
\hline Mean & 1.19 & 3.06 & 7.84 & 1.19 & 3.32 & 8.18 \\
\hline CV (\%) & 13.8 & 6.4 & 4.9 & 21.8 & 4.1 & 3.5 \\
\hline$p$-value & 0.079 & 0.1951 & 0.9094 & 0.6425 & 0.0235 & 0.0002 \\
\hline HSD & - & - & - & - & 0.30 & 0.62 \\
\hline
\end{tabular}

HSD: Tukey's Honestly Significant Difference to separate means. Means within the same column followed by the same letter are not significantly different 
Table 6. Effect of nitrogen level on the number of fibre bundles for different stem segments (top, middle and bottom) under rainfed and irrigation conditions

\begin{tabular}{|c|c|c|c|c|c|c|}
\hline \multirow{2}{*}{$\begin{array}{l}\text { Nitrogen level } \\
\left(\mathrm{kg} \mathrm{ha}^{-1}\right)\end{array}$} & \multicolumn{3}{|c|}{ Rainfed } & \multicolumn{3}{|c|}{ Irrigation } \\
\hline & Top & Middle & Bottom & Top & Middle & Bottom \\
\hline 0 & $165.3 \mathrm{c}$ & $381.5 b c$ & $515.0 \mathrm{~b}$ & $127.5 b$ & $308.5 \mathrm{c}$ & $483.0 \mathrm{c}$ \\
\hline 50 & $166.5 \mathrm{bc}$ & $362.8 \mathrm{c}$ & $624.3 \mathrm{ab}$ & $183.0 \mathrm{a}$ & $379.0 \mathrm{bc}$ & $607.3 \mathrm{~b}$ \\
\hline 100 & $193.0 \mathrm{ab}$ & $473.5 a b$ & $690.5 \mathrm{a}$ & $202.8 \mathrm{a}$ & $430.3 \mathrm{ab}$ & $607.8 \mathrm{~b}$ \\
\hline 150 & $193.5 \mathrm{a}$ & $550.5 \mathrm{a}$ & $757.5 \mathrm{a}$ & $206.0 \mathrm{a}$ & $516.6 \mathrm{a}$ & $878.5 \mathrm{a}$ \\
\hline Mean & 179.6 & 442.1 & 646.8 & 179.8 & 409.6 & 644.1 \\
\hline CV (\%) & 6.8 & 9.5 & 11.3 & 9.2 & 11.0 & 5.1 \\
\hline$p$-value & 0.011 & 0.0004 & 0.0066 & 0.0003 & 0.0007 & $<0.0001$ \\
\hline HSD & 26.8 & 92.4 & 191.4 & 36.6 & 99.6 & 72.9 \\
\hline
\end{tabular}

HSD: Tukey's Honestly Significant Difference to separate means. Means within the same column followed by the same letter are not significantly different

A highly significant decrease $(P<0.01)$ in the number of fibre rings per section as well as the total number of fibre bundles per section in the bottom stem segments with increasing plant population density was found, with 300,000 and 400,000 plants per hectare producing higher numbers of fibre rings than 600,000 plants per hectare (Tables 7 and 8).The number of fibre rings and total number of fibre bundles per section of the middle segment also decreased significantly $(P<0.01)$ with an increase in plant population density (Tables 7 and 8). Therefore, when applying anatomical criteria for comparing the effect of different agronomic treatments on fibre development, it is important to concentrate on the bottom and middle parts of the stem since these are the oldest or more 'mature' parts of the stem, where fibre development is most advanced. 
Table 7. Effect of plant population density and row spacing on the number of fibre rings for different stem segments (top, middle and bottom) under rainfed conditions

\begin{tabular}{|c|c|c|c|}
\hline \multirow{2}{*}{$\begin{array}{l}\text { Plant population } \\
\text { (plants ha-1) }^{-1}\end{array}$} & \multicolumn{3}{|c|}{ Stem segment } \\
\hline & Top & Middle & Bottom \\
\hline 300,000 & $1.67 \mathrm{a}$ & $4.00 \mathrm{a}$ & $10.00 \mathrm{a}$ \\
\hline 400,000 & $1.42 \mathrm{a}$ & $3.58 a b$ & $10.6 \mathrm{a}$ \\
\hline 500,000 & $1.42 \mathrm{a}$ & $3.25 b$ & $9.6 a b$ \\
\hline 600,000 & $1.42 \mathrm{a}$ & $3.25 b$ & $8.7 \mathrm{~b}$ \\
\hline Mean & 1.48 & 3.52 & 9.70 \\
\hline CV (\%) & 39.0 & 15.3 & 7.91 \\
\hline$p$-value & 0.6450 & 0.0065 & $<0.0001$ \\
\hline HSD & - & 0.70 & 1.13 \\
\hline \multicolumn{4}{|l|}{ Row spacing (m) } \\
\hline 0.17 & $1.44 \mathrm{a}$ & $3.38 b$ & $9.44 \mathrm{a}$ \\
\hline 0.34 & $1.38 \mathrm{a}$ & $3.31 \mathrm{~b}$ & $9.69 \mathrm{a}$ \\
\hline 0.50 & $1.63 \mathrm{a}$ & $3.88 \mathrm{a}$ & $10.00 \mathrm{a}$ \\
\hline Mean & 1.48 & 3.52 & 9.71 \\
\hline CV (\%) & 39.0 & 15.3 & 7.9 \\
\hline$p$-value & 0.4556 & 0.0132 & 0.1380 \\
\hline HSD & - & 0.48 & - \\
\hline \multicolumn{4}{|l|}{ Plant pop x RS } \\
\hline Mean & 1.48 & 3.52 & 9.70 \\
\hline CV (\%) & 39.0 & 15.3 & 7.9 \\
\hline$p$-value & 0.4117 & 0.8986 & 0.0148 \\
\hline HSD & - & - & - \\
\hline
\end{tabular}

HSD: Tukey's Honestly Significant Difference to separate means. Means within the same column followed by the same letter are not significantly different 
Table 8. Effect of plant population density and row spacing on the number of fibre bundles for different stem segments (top, middle and bottom) under rainfed conditions

\begin{tabular}{|c|c|c|c|}
\hline \multirow{2}{*}{ 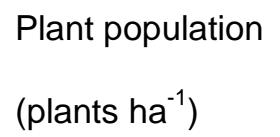 } & \multicolumn{3}{|c|}{ Stem segment } \\
\hline & Top & Middle & Bottom \\
\hline 300,000 & $256.0 \mathrm{a}$ & $639.6 \mathrm{a}$ & $1265.2 \mathrm{a}$ \\
\hline 400,000 & $263.2 \mathrm{a}$ & $593.2 \mathrm{ab}$ & $1136.3 a b$ \\
\hline 500,000 & $210.0 \mathrm{a}$ & $543.5 \mathrm{bc}$ & $1113.6 a b$ \\
\hline 600,000 & $210.2 \mathrm{a}$ & $510.2 \mathrm{c}$ & $996.5 \mathrm{~b}$ \\
\hline Mean & 234.8 & 571.6 & 1127.9 \\
\hline CV (\%) & 12.3 & 6.6 & 9.8 \\
\hline$p$-value & 0.3333 & $<0.0001$ & $<0.0001$ \\
\hline HSD & - & 53.7 & 171.7 \\
\hline \multicolumn{4}{|l|}{ Row spacing (m) } \\
\hline 0.17 & $230.1 \mathrm{a}$ & $571.56 \mathrm{a}$ & $1101.2 \mathrm{a}$ \\
\hline 0.34 & $235.3 a$ & $571.63 \mathrm{a}$ & $1140.7 \mathrm{a}$ \\
\hline 0.50 & $239.1 \mathrm{a}$ & $571.63 \mathrm{a}$ & $1141.8 \mathrm{a}$ \\
\hline Mean & 234.8 & 571.6 & 1127.9 \\
\hline CV (\%) & 12.3 & 6.6 & 9.8 \\
\hline$p$-value & 0.6786 & 1.0000 & 0.5090 \\
\hline HSD & - & - & - \\
\hline \multicolumn{4}{|l|}{ Plant pop x RS } \\
\hline Mean & 234.8 & 571.6 & 1127.9 \\
\hline CV (\%) & 12.3 & 6.6 & 9.8 \\
\hline$p$-value & 0.8157 & $<0.7820$ & 0.6239 \\
\hline HSD & - & - & - \\
\hline
\end{tabular}

HSD: Tukey's Honestly Significant Difference to separate means. Means within the same column followed by the same letter are not significantly different 
Row spacing had no significant effects on either the number of fibre rings or total number of fibre bundles per section of any of the stem segments, except for the middle segment, where the wider row spacing $(0.50 \mathrm{~m})$ gave a higher number of fibre rings (Tables 7 and 8 ). It is, therefore, clear that the number of plants per row (in-row spacing, and therefore total plant population) had a greater effect on fibre development and plant performance than row spacing.

\section{Discussion}

Kenaf fibres are truly ligno-cellulose fibres. Ayre et al. (2009) stated that the cell walls of kenaf phloem fibres are composed of cellulose and non-cellolosic substances such as "hemicelluloses, pectins and lignins". Figures 4A and 4B confirm the presence of lignin in the fibre cell walls, in contrast to the cellulose walls of the adjacent parenchyma cells. The primary phloem fibres also did not stain with

phloroglucinol (Figure 1B), showing that they contain no lignin, similar to the cellulose fibres of ramie (Boehmeria nivea) and flax (Linum usitatissimum), which Maiti (1979) classified as primary phloem (pericycle) fibres.

An increase in stem diameter of kenaf, as was observed in the present study, is the direct result of the activity of the vascular cambium causing an increase in the volume of core and bark. The increase in thickness of the bark from the top to the bottom of the stem is the result of the formation of successive concentric fibre bundle rings outside the vascular cambium during secondary thickening growth. Firstformed fibre rings are pushed outwards by newly formed rings, causing the dilation of phloem rays to prevent cracking of the stem. This observation agrees with the findings of Ayre et al. (2009), who reported an increase in stem girth of kenaf as a result of the formation of successive rings of fibre bundles by the vascular cambium. 
The increase in the number of fibre bundles per ring was the result of an increase in the diameter of the secondary phloem. The results of the present study highlight the fact that the effect of any agronomic practice on kenaf stem diameter depends on the response of vascular cambium cell activity. Higher nitrogen fertilization levels probably improved the activity of the cambium cells, while higher plant populations tended to reduce the activity of those cells, presumably due to higher inter-plant competition. Apparently the vascular cambium cells did not respond significantly to changes in row spacing.

The increase in stem height with an increase in nitrogen level may be due to improved availability, uptake, and assimilation of this nutrient by plants, as well as its effect on cell activity. According to Cechin and De Fatima (2004), metabolic processes in the plant are totally dependent upon nitrogen availability. Furthermore, MacAdam et al. (1989) found an increase in cell elongation with an increase in nitrogen supply. An increase in stem height and diameter with increasing nitrogen level was also reported by Kuchinda et al. (2001).

The decrease in stem height with an increase in plant population density can probably be attributed to an increase in pressure on growth resources, reducing the availability of those resources under high plant population density due to higher interplant competition for nutrients and light. Similar to the present study, a reduction in both plant height and stem diameter of kenaf due to an increase in plant population density was also observed in other studies (Danalatos and Archontoulis 2004).

It has to be noted that the effects of any agronomic practice on cell activity can indirectly result from its effect on other growth factors, including the availability of nutrients, water and light. This was evident by the performance of the plants grown 
under the same rate of nitrogen, but with different levels of water supply (Table 3). For example with $50 \mathrm{~kg} \mathrm{ha}^{-1}$ of nitrogen, the rainfed plants reached a height of 200 $\mathrm{cm}$ versus $223 \mathrm{~cm}$ under irrigation.

\section{Conclusions}

Although the results of the present study confirmed earlier findings on the effects of agronomic practices on stem height and diameter via diameter (thickness) of segments, the mechanism of how this occurs had not been elucidated before. The present study revealed how agronomic practices can affect stem diameter (thickness) through fibre development. Furthermore, the study demonstrated that the use of anatomical criteria can be useful to assess the effect of agronomic practices on fibre production in kenaf stems.

Finally, when growing kenaf for fibre production, the aim is to gain the best possible economic return, which can only be achieved by producing more fibre per plant or per unit area. This can only be achieved if more fibre rings and fibre bundles are developed per individual plant. Under local conditions, $150 \mathrm{~kg} \mathrm{ha}^{-1}$ of nitrogen applied in two splits, 300,000 plants per hectare and $0.50 \mathrm{~m}$ row spacing was the best combination of agronomic practices in terms of fibre development per plant. However, for the best economic decision, a balance between the number of plants per unit area and quantity of fibre produced per plant should be taken into account. This study was conducted on plants sampled at five weeks before final harvesting. These findings also need to be confirmed at the time of final harvest and hence further studies are encouraged to confirm these findings. As far as could be established, this study constitutes the first step in investigating the effect of 
agronomic practices on fibre development of kenaf by using anatomical characteristics as criteria.

\section{Acknowledgements}

Funding of the study by Sustainable Fiber Solution (SFS), the National Research Foundation (NRF)-Thuthuka and The Reconstruction and Development Programme (RDP) is gratefully acknowledged. The research team is also indebted to Jacques Marneweck, Ronnie Gilfillan and Samuel Mudau for technical assistance.

\section{References}

Abdul Khalil HPS, Ireana Yusra AF, Bhat AH, Jawaid M. 2010. Cell wall ultrastructure, anatomy, lignin distribution, and chemical composition of Malaysian cultivated kenaf fiber. Industrial Crops and Products 31:113-121.

Agbaje GO, Saka JO, Adegbite AA, Adeyeye OO. 2008. Influence of agronomic practices on yield and profitability in kenaf (Hibiscus cannabinus L.) fibre cultivation. African Journal of Biotechnology 7: 565-574.

Ahmed AM, Jalaluddin H, Noor ISA, Harmaen AS. 2008. Suitability of kenaf (Hibiscus cannabinus L.) soda-AQ pulp for manufacture of linerboard, Proceedings colloquium of kenaf research out put 1-2 December 2008. Serembani, Negeri Sembilan Malaysia Universiti Putra Malasia.

Annandale JG, Banadé N, Jovanovic NZ, Steyn JM, DU Sautoy N. 1999. Facilitating irrigation scheduling by means of the soil water balance model. Water Research Commission Rep. N0 753/1/99, Pretoria, South Africa. 
Ayre BG, Chapman KD, Dagnon KL, D'Souza NA, Stevens and K, Webber CL. 2009. Viscoelastic properties of kenaf bast fiber in relation to stem age. Textile Research Journal 79: 973-980.

Banüelos GS, Bryla DR, Cook CG. 2002. Vegetative production of kenaf and canola under irrigation in central California. Industrial Crops and Products 15: 237245.

Calamari TA, Tao W, Goynes WR. 1997. A preliminary study of kenaf fiber bundles and their composite cells. Tappi Journal 80: 149-154.

Cechin I, De Fatima TF. 2004. Effect of nitrogen supply on growth and photosynthesis of sunflower plants grown in the greenhouse. Plant Science 166: $1379-1385$.

Chantiratikul A, Chaikong C, Chinrasri O, Kangkun P. 2009. Evaluation of yield and nutritive value of kenaf (Hibiscus cannabinus) at various stages of Maturity. Pakistan Journal of Nutrition 8: 1055-1058.

Chiaiese P, Ruotolo G, Dimatteo A, De Santo Virzo A, De Marco A, Filippone E. 2011. Cloning and expression analysis of kenaf (Hibiscus cannabinus L.) major lignin and cellulose biosynthesis gene sequences and polymer quantification during plant development. Industrial Crops and Products34: 1072-1078.

Danalatos N, Archontoulis SV. 2004. Potential growth and biomass productivity of kenaf under central Greek conditions: II. The influence of variety, sowing time and plant density. In: Van Swaalj WPM, Fjalistrom T, Helm P, Grassi A. (Ed.), Biomass for Energy, Industry and Climate Protection. Proceedings of the 2nd World Biomass Conference, 10-14 May 2004, Roma, Italy. 
Dempsey JM. 1975. Fiber crops. The Univ. Presses of Florida, Gainesville.

Fike WT. 1990. The rise and fall of kenaf as a fiber crop in North Carolina. In: J. Janick and J.E. Simon (eds.), Advances in new crops. Timber Press, Portland, OR. p. 297-299.

H'ng PS, Khor BN, Tadashi N, Aini ASN, Paridah MT. 2009. Anatomical structures and fiber morphology of new varieties. Asian Journal of Scientific Research 2: 161-166.

Han JS, Mianowski T, Lin YY. 1999. Validity of plant fiber length measurement - a review of fiber length measurement based on kenaf as a model. In: Kenaf Properties, Processing and Products; Mississippi State University, Ag \& Bio Engineering. pp. 149-167.

Hossain M, Hanafi M, Jol H, Hazandy A. 2011. Growth, yield and fiber morphology of kenaf (Hibiscus cannabinus L.) grown on sandy bris soil as influenced by different levels of carbon. African Journal of Biotechnology 10: 10087-10094.

Hossain MdD, Musa HM, Talib J, Jol H. 2010. Effects of nitrogen, phosphorus and potassium levels on kenaf (Hibiscus cannabinus L.) growth and photosynthesis under nutrient solution. Journal of Agricultural Science 2: 4957.

Jensen WA. 1962. Botanical histochemistry: Principles and Practice. FWH Freeman and Company, San Francisco.

Kayembe KP. 2015. Kenaf (Hibiscus cannabinus L.) fibre yield and quality as affected by water, nitrogen, plant population and row spacing. MSc Thesis, University of Pretoria, Pretoria, South Africa. 
Koning RE. 1994. Secondary growth. Plant Physiology Information. http://plantphys. info/plant biology/secondary.shtml. (Accessed 08-08-2016).

Kuchinda NC, Ndahi WB, Lagoke STO, Ahmed MK. 2001. The effects of nitrogen and period of weed interference on the fibre yield of kenaf (Hisbiscus cannabinus L.) in the northern Guinea Savanna of Nigeria. Crop Protection 20: 229-235.

MacAdam JR, Volenec JJ, Nelson CJ. 1989. Effects of Nitrogen on Mesophyll Cell Division and Epidermal Cell Elongation in Tall Fescue Leaf Blades. Plant Physiology 89: 549-556.

Maiti RK. 1979. A study of the microscopic structure of the fiber starnds of common Indian bast fibers and its economic implications. Economic Botany 33:78-87.

Maiti RK and Dagupta A. 1972. Comparison microscopy of ten varieties of Mesta (kenaf) in relation to yield and quality. Textiles Research Journal 42: 648-649.

O'Brien TP, McCully ME. 1981. The study of plant structure: principles and selected methods, Melbourne, Termarcarphi Pty LTD.

Ochi S. 2008. Mechanical properties of kenaf fibers and kenaf/PLA composites. Mechanics of Materials 40:446-452.

Ogbonnaya Cl., Roy-Macauley H, Nwalozie MC. Annerose DJM. 1997. Physical and histochemical properties of kenaf (Hibiscus cannabinus L.) grown under water deficit on a sandy soil. Industrial Crops Products 7: 9-18.

Paraskevopoulou A. 1987. Variation of wood structural features of cypress (Cupressus sempervirens) in Greece. Ph.D. Thesis, Institute of General Botany, University of Athens. 
Ramaswamy GN, and Easter EP. 1997. Durability and Aesthetic Properties of Kenaf/Cotton Blend Fabrics. Textile Research Journal 67: 803-808.

Rashidi AAAb, Sapuan SM, Ahmad MMHM, Abdan Kbt. 2009. Review of kenaf fiber reinforced polymer composites. Department of Mechanical and Manufacturing Engineering, Universiti Putra Malaysia UPM 43400 Serdang, Selangor, Malaysia.

Raven PH, Evert RF and Eichhorn SE. 1992. Biology of Plants. Wortyh Publishers, New York.

Sabharwal HS, Aktar M, Blanchette RA, Young RA. 1994. Biomechanical pulping of kenaf. Tappi Journal 77: 105-112.

SAS: Statistical Analysis Software. 2002-2010. Version 9.3.SAS Institute Inc, Cary, NC, USA.

Shakhes J, Dehghani-Firouzabadi MR, Rezarati-Chirami D, Zeinaly F. 2010. Evaluation of harvesting time effects and cultivars of kenaf on papermaking. BioResources 5: 1268-1280.

Tahir PMD, Ahmed AB, Saiful Azry SOA, Ahmed Z. 2011. Retting process of some bast plant fibres and its effect on fibre quality: A Review. BioResources 5: $5260-5281$.

Tao W, Calamari TA, Shih FF and Cao C. 1997. Characterization of kenaf fiber bundles and their nonwoven mats. Tappi Journal 80: 162-166.

Ververis C, Georghiou K, Christodoulakis N, Santas P, Santas R. 2004. Fiber dimensions, lignin and cellulose content of various plant materials and their suitability for paper production. Industrial Crops and Products 19: 245-254. 
Voulgaridis E, Passialis C \& Grigorion A. 2000. Anatomical characteristics and properties of kenaf stems (Hibiscus cannabinus). IAWA Journal 21: 435-442.

Webber III CL, Bledsoe VK, Bledsoe RE. 2002. Kenaf harvesting and processing. Reprinted from: Trends in new crops and new uses. 2002. J. Janick and A. Whipkey (eds.). ASHS Press, Alexandria, VA.

Webber III CL, White Jr PM, Dalley C, Petrie EC, Viator RP, Shrefler JW. 2016. Kenaf (Hibiscus cannabinus) and Cowpea (Vigna unguiculata) as Sugarcane Cover Crops. Journal of Agricultural Science 8: 13-20.

Zhou C, Ohtani Y, Sameshima K, Zhen M. 1998. Selection of plant population of kenaf (Hibiscus cannabinus L.) as a papermaking raw material on arid hillside land in China. Tha Japan Wood Research Society 44: 296-302. 